\title{
Myocardial infarction with non-obstructive coronary arteries
}

\section{Zawat serca bez istotnych zmian w tętnicach wieńcowych}

\author{
Marcin Sadowski, Łukasz Rekść, Aleksander Stępień, Jakub Kuchinka, Paweł Zieliński, Marek Grabski, \\ Patrycja Ręba, Edyta Barańska
}

Institute of Medical Sciences, Faculty of Medicine and Health Sciences, Jan Kochanowski University, Kielce, Poland Head of the Institute: Prof. JKU Beata Kręcisz MD, PhD

Key words: myocardial infarction, myocardial infarction with non-obstructive coronary arteries, female.

Słowa kluczowe: zawał serca, zawał serca bez istotnych zmian w nasierdziowych tętnicach wieńcowych, kobiety.

\begin{abstract}
Myocardial infarction with non-obstructive coronary arteries (MINOCA) is a working diagnosis in about 10\% of cases presenting with symptoms suggestive of acute myocardial ischaemia and no significant atherosclerotic plaques in coronary angiography. It is a heterogenous clinical entity with a complex aetiology and always requires a challenging work-up. The final diagnosis may confirm any coronary pathology (dissection, spasm, thrombus) or significantly differ from the previous one (myocarditis, takotsubo cardiomyopathy). This paper focuses on the current knowledge on MINOCA, guidelines on the management of patients, and indicates new research areas to further elucidate this issue. The most important message is that MINOCA is a serious condition with outcomes at least as serious as in myocardial infarction resulting from coronary atherosclerosis.
\end{abstract}

\section{Streszczenie}

Zawał serca bez istotnych zmian w nasierdziowych tętnicach wieńcowych (MINOCA) to robocze rozpoznanie ustalane w ok. 10\% przypadków, w których w koronarografii nie stwierdza się istotnych zwężeń miażdżycowych, a objawy kliniczne silnie sugerują podłoże niedokrwienne. Choroba stanowi istotne wyzwanie diagnostyczne ze względu na heterogenną etiologię i zawsze wymaga uważnego podejścia. Ostateczna diagnoza może potwierdzić przyczynę wieńcową (dysekcja, skurcz, zakrzep) lub znacznie różnić się od wstępnego rozpoznania (zapalenie mięśnia serca, kardiomiopatia takotsubo). W artykule przedstawiono zarys współczesnej wiedzy na temat MINOCA, obowiązujące zalecenia dotyczące diagnostyki i terapii oraz wskazano nowe kierunki badań niezbędnych do pełnego wyjaśnienia tego zagadnienia. Najważniejszym przesłaniem pracy jest wniosek, że mimo braku zwężeń w tętnicach wieńcowych MINOCA jest zespołem chorobowym o rokowaniu co najmniej tak poważnym jak w zawale serca o podłożu miażdżycowym.

\section{Introduction}

The management of patients with acute myocardial infarction (MI) resulting from a total occlusion of the infarct-related artery has been sufficiently documented [1]. In case of successful primary coronary intervention, the patient's recovery is usually uneventful [1]. The decision-making process is troubled by a confusing finding of non-obstructive coronary arteries in coronary angiography simultaneously with a typical electrocardiography (ECG) pattern of acute MI. This situation is well known since the pioneering studies by DeWood demonstrating that up to $10 \%$ of patients with MI had no significant coronary stenosis [2]. The term myocardial infarction with non-obstructive coronary arteries (MINOCA) was initially used by Beltram in 2013 [2] and emphasises a variety of dis- orders responsible for this intriguing clinical scenario [3]. This paper is focused on the current knowledge and guidelines on MINOCA and summarises future perspectives.

\section{Definition of MINOCA}

According to the European Society of Cardiology working group [4], MINOCA is a working diagnosis that requires further work-up. It is applicable in the combination of clinical symptoms of MI, positive cardiac biomarkers, and demonstration of non-obstructive coronary arteries. The detailed criteria are presented in Table 1 (all must apply). It can be clearly seen that cardiac troponin ( $\mathrm{cTn}$ ) release must be in direct relation to myocardial ischaemia resulting from any coronary pathology. Otherwise, the term 
troponin-positive non-obstructive coronary arteries (TP-NOCA) seems to be more appropriate (Table 2) [5]. The definition of MINOCA allows the inclusion of patients with mild coronary atheromatosis (i.e. stenoses up to $50 \%$ ), which makes the selected group very heterogenic. An arbitrary decision on a 50\% limit together with an intra- and inter-observer variability and the dynamic nature of coronary pathologies including vasoconstriction, thrombus autolysis, intraplaque haemorrhage or a combination of them make this limit elusive. This probably prompted McCabe et al. [6] to create a conception of a false positive MI, which fortunately is no longer valid. Surprisingly, there is no standard definition of "normal coronary arteries" because coronary atheromatosis is frequently eccentric [7], and coronary angiography provides a limited amount of data on the arterial lumen only. Additionally, a wide spectrum of diseases may be responsible for the significant cardiac troponin release [8], which makes this marker useless in further diagnostic pathways. Therefore, this binary approach (i.e. troponin = infarct) should be avoided because the troponin is organ-specific, but not disease-specific.

\section{ESC guidelines and MINOCA}

\section{NSTE-ACS (2015)}

The 2015 guidelines for the management of acute coronary syndromes in patients presenting without persistent ST-segment elevation (NSTEACS) [9] lack the term MINOCA in the subset of non-ST-elevation myocardial infarction (NSTEMI) patients. However, the authors mention normal coronary arteries, takotsubo cardiomyopathy, coronary embolism, and spasm as potential causes for MI. Interestingly, microvascular dysfunction is given as a main - although mild to moderate - cause for coronary instability, but the reader is directed to guidelines for stable angina.

\section{STEMI (2017) and $4^{\text {th }}$ UDMI (2018)}

Guidelines for the management of patients with ST-segment elevation myocardial infarction (STEMI) [1] and the $4^{\text {th }}$ Universal Definition of Myocardial Infarction (UDMI) [8] refer to the position paper mentioned above [5] and indicate a $1-14 \%$ rate of MINOCA. They also introduce a new category of pa-
Table 1. Diagnostic criteria for MINOCA (based on [4])

Acute $\mathrm{MI}$ criteria according to the $4^{\text {th }}$ Universal Definition of Myocardial Infarction (positive cardiac biomarkers together with clinical evidence of myocardial ischaemia) [8]

Non-obstructive coronary arteries in coronary angiography including:

- no coronary artery stenosis $\geq 50 \%$ in any potential infarct-related artery

- angiographically normal coronary arteries (no

stenosis > 30\%)

- mild stenoses (30-50\%)

At the time of angiography, no clinically overt specific cause is present.

tients with elevated cTn serum levels, namely myocardial injury, because currently it is not possible to discriminate specific individual mechanisms resulting in cTn release. Therefore, four reasons for cTn elevation may be distinguished: a) acute myocardial ischaemia due to atherosclerotic plaque disruption with thrombosis (type $1 \mathrm{MI}$ ), b) acute myocardial ischaemia due to oxygen supply/demand imbalance (type $2 \mathrm{MI}$ ), and other c) cardiac and d) systemic conditions. These valuable papers seem to be mandatory reading for all physicians dealing with patients in acute settings.

\section{Pregnancy 2018}

Guidelines for the management of cardiovascular diseases during pregnancy [10] cover the entire spectrum of MINOCA in pregnant women. The pregnancy itself is associated with a three- to four-fold increase in MI risk. Most coronary causes are non-atherosclerotic, including pregnancy-related spontaneous coronary artery dissection (P-SCAD, 43\%), angiographically normal coronary arteries (18\%), and coronary thrombosis (17\%). P-SCAD is responsible for $43 \%$ of MINOCA cases and is most commonly present in the left-sided coronary arteries during late pregnancy or early postpartum. A multifactorial aetiology is ascribed to this condition including oestrogen/progesterone imbalance, fibromuscular dysplasia, connective tissue diseases, and increased coronary shear stress. The MI with normal arteries usually results from transient coronary spasm, while thrombotic aetiology may be a consequence of pregnancy-related hypercoagula-

Table 2. Troponin-positive non-coronary arteries (based on [4, 5])

\begin{tabular}{|lll|}
\hline Coronary disorders (MINOCA) & \multicolumn{1}{c|}{ Myocardial disorders } & \multicolumn{1}{c|}{ Non-cardiac disorders } \\
- Plaque disruption (rupture, ulceration, erosion, & - Myocarditis & - Pulmonary embolism \\
intraplaque haemorrhage) & - Takotsubo cardiomyopathy & • Renal impairment \\
- Dissection & - Postpartum cardiomyopathy & \\
- Spasm & - Other \\
- Microvascular dysfunction & & \\
- Thromboembolism & \\
\hline
\end{tabular}

MINOCA - myocardial infarction with non-obstructive coronary arteries. 
bility or rare cases of paradoxical embolisation [11]. The guidelines do not include peri-partum cardiomyopathy (PPCM) as a potential trigger of MINOCA; however, a presentation of typical acute retrosternal chest pain in a young breast-feeding female together with STEMI pattern on ECG and significant cTn rise is highly suggestive of acute MI, and many such patients undergo coronary angiography. The treatment is aetiology-dependent; however, in the case of SCAD an invasive approach is discouraged because dissections may aggravate due to the impaired structure of the vascular wall.

\section{MINOCA in the real-life population}

In the VIRGO study on 2690 young $(<55$ years old) patients with acute MI MINOCA occurred in 11.1\% and was most likely in women with less classic coronary risk factors and with a heterogeneous mechanistic profile of the coronary aetiology. The outcomes were similar to those having coronary atheromatosisrelated MI [12]. In the systematic review of 12 trials including 176,502 patients with MI MINOCA occurred predominantly in women with NSTEMI, the rate was similar to the one in the VIRGO study (1-14\%), the most common final diagnosis was myocarditis (30\%), while others were induced spasm (27\%), takotsubo cardiomyopathy (20\%), and thrombophilia (14\%) [13].

\section{Diagnostic work-up for MINOCA}

Immediately after the coronary angiography, if the diagnosis of TP-NOCA is certain, the attending physician must categorise the patient into one of three groups: MINOCA, myocardial disorder, or non-cardiac disorder. If the diagnosis of MINOCA is confirmed, diagnostic work-up is mandatory. The most important area of investigation is the possible coronary (either epicardial or microvascular) nature of the disease. Before further steps are made the operator is obliged to review the cine runs for any subtle angiographic findings (i.e. dissections or emboli) and consider intravascular imaging or provocative spasm testing $[1,4,5,8]$. Although this guideline seems reasonable, the environment of the catheterisation laboratory in the setting of acute MI during a night shift is significantly different from the core lab facilities with researchers sensitive to unique findings. Consequently, many subtle findings are simply overlooked. Finally, not all labs are equipped with sophisticated imaging devices. Nonetheless, all guidelines insist on reconsidering coronary aetiology as the primary cause because the accuracy of a direct visual assessment of the arterial lumen is not perfect. As reported by Reynolds et al., up to $40 \%$ of female patients with MINOCA have a plaque disruption (i.e. erosion or ulceration) non-demonstrable in angiography, but clearly visible in the intravascular ultrasound and confirmed by T2 signal hyperintensity in cardiac magnetic resonance imaging (cMRI) indicating myocardial cell oedema due to the temporary ischaemia [14].

Because myocarditis is the most frequent reason for cTn release in this subset of patients, it should always be included into the differential diagnosis, especially when the pathology in epicardial arteries has been ruled out as a primary cause. cMRI is the next step in the management, to look for non-ischaemic patterns. For final confirmation, a myocardial biopsy is needed, frequently followed by immunohistology and polymerase-chain reaction techniques for known infectious agents DNA search [4].

There is a growing body of evidence for the usefulness of cMRI in patients with MINOCA because it allows for an almost $90 \%$ rate of specific diagnosis. Frequently, it is the only chance to document transient myocardial ischaemia in cases of angiographically non-demonstrable plaque disruption or spontaneous lysis of the thrombus [15]. In this case, the work-up for the thromboembolism is complex, and time- and resource-consuming; however, it remains the inevitable consequence of the previous finding.

For the confirmation of takotsubo cardiomyopathy a follow-up imaging is required to document recovery of the left ventricular function, so in the acute phase it may be suspected only [4].

The pulmonary embolism can be diagnosed effectively with the combination of clinical symptoms, clinical probability, serum D-dimer, echocardiographic findings of right ventricular overload, and computed tomography angiography [4].

Type 2 MI represents a broad spectrum of cardiac and non-cardiac mechanisms including, but not limited to, severe tachy- and bradyarrhythmias, severe arterial hypertension with ventricular hypertrophy, respiratory failure, severe anaemia, and shock $[4,9]$. The management is frequently very challenging, and many potential medical errors may be encountered. The most common clinical scenario with fatal sequel is acute gastrointestinal bleeding or perforation manifesting as acute epigastric pain with significant ECG ischaemic pattern, followed by the diagnosis of acute coronary syndrome and subsequent dual antiplatelet and unfractionated heparin treatment.

\section{The treatment}

Unfortunately, there is no specific treatment for MINOCA. A gold standard for type $1 \mathrm{MI}$, percutaneous coronary intervention, is not valid in a significant proportion of patients with MINOCA. Medical treatment remains the only option; however, no specific agent has been dedicated in this subset of patients. The SWEDEHEART registry provided some additional data on the medical therapy proving the efficiency of statins and renin-angiotensin-aldosterone system blockade and failure of dual antiplatelet therapy in the prevention of cardiovascular events [16]. We are 
awaiting results of the MINOCA-BAT study (Randomised Evaluation of Beta Blocker and ACEI/ARB Treatment in MINOCA Patients); however, the recruitment has not started yet [17].

\section{The prognosis}

MINOCA must not be considered as a benign clinical entity. The outcomes greatly depend on the primary cause. Pasupathy et al. reported 0.9\% in-hospital mortality and $4.7 \%$ annual mortality [13]. In the SWEDEHEART registry there was a $24 \%$ rate of major cardiovascular events and 14\% mortality during a 4.5year follow-up [18]. In the VIRGO study females with MINOCA had two-fold higher mortality than their healthy counterparts [12]. In the CRUSADE registry female sex and young age were the only predictors of MINOCA [19]. These data clearly demonstrate that the outcomes after MINOCA are at least as poor as in type 1 MI. In more than half of patients after MINOCA episode, mostly in women, a full clinical manifestation of coronary artery disease including MI develops during the two following years, while a new MINOCA occurs in the remainder [20].

\section{Gaps in evidence}

The heterogeneity of MINOCA requires a widely accepted diagnostic algorithm. This should prompt international data collection into a unified register because a large sample size is needed to provide reliable conclusions on the prevalence and outcomes. Therefore, multicentre cooperation is warranted to achieve this goal. Simultaneously, large and adequately powered randomised trials are needed to validate well documented and novel therapies of patients with MINOCA.

\section{Conclusions}

MINOCA is a working diagnosis and always requires further elucidation. It predominantly exists in young females presenting with NSTEMI. This diagnosis should be limited to patients with a documented myocardial ischaemia/infarction related to coronary pathology (i.e. plaque disruption, thromboembolism, spasm). The diagnostic work-up is frequently complex, time- and resource-consuming, and usually requires cMRI as a key test. The data on medical management are scarce, so a personalised approach is strongly advised to address the underlying mechanism as precisely as possible [21].

\section{Conflict of interest}

The authors declare no conflict of interest.

\section{References}

1. Ibanez B, James S, Agewall S, Antunes MJ, BucciarelliDucci C, Bueno H, Caforio ALP, Crea F, Goudevenos JA, Halvorsen S, Hindricks G, Kastrati A, Lenzen MJ, Pres- cott E, Roffi M, Valgimigli M, Varenhorst C, Vranckx P, Widimský P; ESC Scientific Document Group. 2017 ESC Guidelines for the management of acute myocardial infarction in patients presenting with ST-segment elevation: The Task Force for the management of acute myocardial infarction in patients presenting with ST-segment elevation of the European Society of Cardiology (ESC). Eur Heart J 2018; 39: 119-77.

2. DeWood MA, Spores J, Notske R, Mouser LT, Burroughs R, Golden MS, Lang HT. Prevalence of total coronary occlusion during the early hours of transmural myocardial infarction. N Engl J Med 1980; 303: 897-902.

3. Beltrame JF. Assessing patients with myocardial infarction and nonobstructed coronary arteries (MINOCA). J Intern Med 2013; 273: 182-5.

4. Agewall S, Beltrame JF, Reynolds HR, Niessner A, Rosano G, Caforio AL, De Caterina R, Zimarino M, Roffi M, Kjeldsen K, Atar D, Kaski JC, Sechtem U, Tornvall P; WG on Cardiovascular Pharmacotherapy. ESC working group position paper on myocardial infarction with non-obstructive coronary arteries. Eur Heart J 2017; 38: 143-53.

5. Pasupathy S, Tavella R, Beltrame JF. Myocardial infarction with nonobstructive coronary arteries (MINOCA): the past, present, and future management. Circulation 2017; 135: 1490-3.

6. McCabe JM, Armstrong EJ, Kulkarni A, Hoffmayer KS, Bhave PD, Garg S, Patel A, MacGregor JS, Hsue P, Stein JC, Kinlay S, Ganz P. Prevalence and factors associated with false-positive ST-segment elevation myocardial infarction diagnoses at primary percutaneous coronary intervention-capable centers: a report from the Activate-SF registry. Arch Intern Med 2012; 172: 864-71.

7. Nissen SE, Gurley JC, Grines CL, Booth DC, McClure R, Berk M, Fischer C, DeMaria AN. Intravascular ultrasound assessment of lumen size and wall morphology in normal subjects and patients with coronary artery disease. Circulation 1991; 84: 1087-99.

8. Thygesen K, Alpert JS, Jaffe AS, Chaitman BR, Bax JJ, Morrow DA, White HD; ESC Scientific Document Group. Fourth universal definition of myocardial infarction (2018). Eur Heart J 2018; doi: 10.1093/eurheartj/ehy462. [Epub ahead of print].

9. Roffi M, Patrono C, Collet JP, Mueller C, Valgimigli M, Andreotti F, Bax JJ, Borger MA, Brotons C, Chew DP, Gencer B, Hasenfuss G, Kjeldsen K, Lancellotti P, Landmesser U, Mehilli J, Mukherjee D, Storey RF, Windecker S; ESC Scientific Document Group. 2015 ESC Guidelines for the management of acute coronary syndromes in patients presenting without persistent ST-segment elevation: Task Force for the Management of Acute Coronary Syndromes in Patients Presenting without Persistent ST-Segment Elevation of the European Society of Cardiology (ESC). Eur Heart J 2016; 37: 267-315.

10. Regitz-Zagrosek V, Roos-Hesselink JW, Bauersachs J, Blomström-Lundqvist C, Cífková R, De Bonis M, Iung B, Johnson MR, Kintscher U, Kranke P, Lang IM, Morais J, Pieper PG, Presbitero P, Price S, Rosano GMC, Seeland U, Simoncini T, Swan L, Warnes CA; ESC Scientific Document Group. 2018 ESC Guidelines for the management of cardiovascular diseases during pregnancy. Eur Heart J 2018; 39: 3165-241.

11. Zachura M, Piątek Ł, Kurzawski J, Janion M. Coronary embolism causing acute myocardial infarction. Review of the literature. Medical Studies 2016; 32: 131-5. 
12. Safdar B, Spatz ES, Dreyer RP, Beltrame JF, Lichtman JH, Spertus JA, Reynolds HR, Geda M, Bueno H, Dziura JD, Krumholz HM, D'Onofrio G. Presentation, clinical profile, and prognosis of young patients with myocardial infarction with nonobstructive coronary arteries (MINOCA): results from the VIRGO study. J Am Heart Assoc 2018; 7. pii: e009174.

13. Pasupathy S, Air T, Dreyer RP, Tavella R, Beltrame JF. Systematic review of patients presenting with suspected myocardial infarction and nonobstructive coronary arteries. Circulation 2015; 131: 861-70.

14. Reynolds HR, Srichai MB, Iqbal SN, Slater JN, Mancini GB, Feit F, Pena-Sing I, Axel L, Attubato MJ, Yatskar L, Kalhorn RT, Wood DA, Lobach IV, Hochman JS. Mechanisms of myocardial infarction in women without angiographically obstructive coronary artery disease. Circulation 2011; 124: 1414-25.

15. Pathik B, Raman B, Mohd Amin NH, Mahadavan D, Rajendran S, McGavigan AD, Grover S, Smith E, Mazhar J, Bridgman C, Ganesan AN, Selvanayagam JB. Troponin-positive chest pain with unobstructed coronary arteries: incremental diagnostic value of cardiovascular magnetic resonance imaging. Eur Heart J Cardiovasc Imaging 2016; 17: $1146-52$

16. Lindahl B, Baron T, Erlinge D, Hadziosmanovic N, Nordenskjöld A, Gard A, Jernberg T. Medical therapy for secondary prevention and long-term outcome in patients with myocardial infarction with nonobstructive coronary artery disease. Circulation 2017; 135: 1481-9.

17. https://clinicaltrials.gov/ct2/show/NCT03686696 (Accessed October, 12, 2018).

18. Nordenskjöld AM, Baron T, Eggers KM, Jernberg T, Lindahl B. Predictors of adverse outcome in patients with myocardial infarction with non-obstructive coronary artery (MINOCA) disease. Int J Cardiol 2018; 261: 18-23.

19. Gehrie ER, Reynolds HR, Chen AY, Neelon BH, Roe MT, Gibler WB, Ohman EM, Newby LK, Peterson ED, Hochman JS. Characterization and outcomes of women and men with non-ST-segment elevation myocardial infarction and nonobstructive coronary artery disease: results from the Can Rapid Risk Stratification of Unstable Angina Patients Suppress Adverse Outcomes with Early Implementation of the ACC/AHA Guidelines (CRUSADE) quality improvement initiative. Am Heart J 2009; 158: 688-94.

20. Nordenskjold AM, Lagerqvist B, Baron T, Jernberg T, Tornvall P, Lindahl B. Reinfarction in patients with previous myocardial infarction with nonobstructive coronary arteries (MINOCA), findings at coronary angiography. Eur Heart J 2018; 39 Suppl 1: 1256.

21. Tavella R, Pasupathy S, Beltrame JF. MINOCA - a personalised medicine approach. Int J Cardiol 2018; 267: 54-5.

\section{Address for correspondence:}

Marcin Sadowski MD

Institute of Medical Sciences

Faculty of Medicine

and Health Sciences

Jan Kochanowski University

al. IX Wieków Kielc 19A, 25-317 Kielce, Poland

Phone: +48 413496973

E-mail: msadowski@ujk.edu.pl 